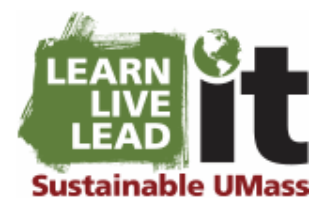

University of Massachusetts Amherst ScholarWorks@UMass Amherst

\title{
Governing Knowledge Commons
}

Charlie Schweik

cschweik@umass.edu

Follow this and additional works at: https://scholarworks.umass.edu/ sustainableumass_educationresources

Part of the Labor Economics Commons, Organizational Behavior and Theory Commons, Organization Development Commons, and the Political Theory Commons

cC) (i)

This work is licensed under a Creative Commons Attribution 4.0 License.

Schweik, Charlie, "Governing Knowledge Commons" (2020). Sustainability Education Resources. 45. Retrieved from https://scholarworks.umass.edu/sustainableumass_educationresources/45

This Article is brought to you for free and open access by the Sustainable UMass at ScholarWorks@UMass Amherst. It has been accepted for inclusion in Sustainability Education Resources by an authorized administrator of ScholarWorks@UMass Amherst. For more information, please contact scholarworks@library.umass.edu. 


\section{SPP 597GC and NRC597GC - Governing Knowledge Commons Fall 2020, UMass Amherst \\ 3 Credits, M\&W 4:00 pm - 5:15 pm}

online (synchronous, asynchronous or hybrid -- whatever works for you!)

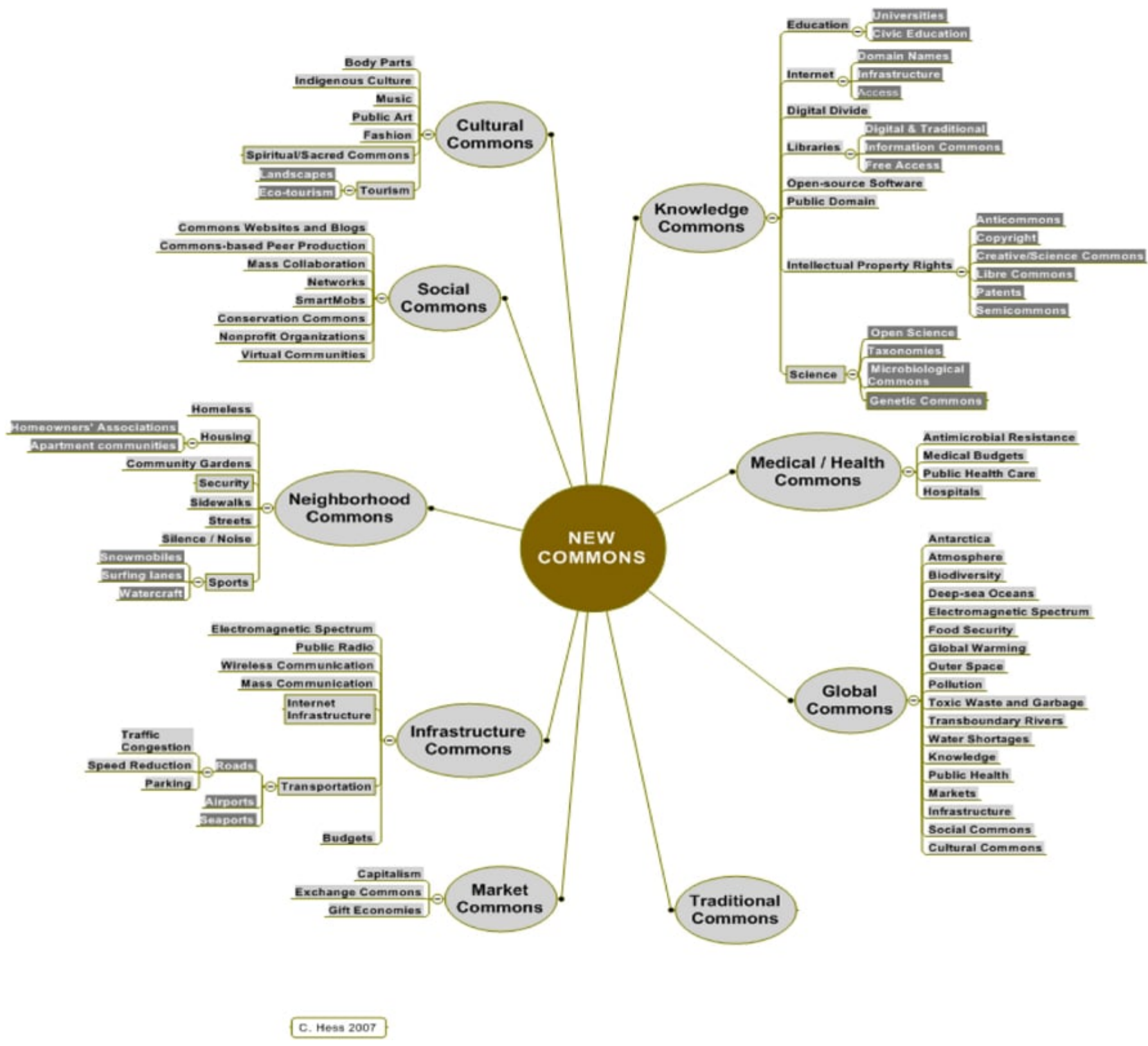

Seminar facilitator:

Dr. Charles Schweik cschweik@umass.edu

Office hours: Tuesdays and Thursdays, 3:00-4:00 pm at https://umass-amherst.zoom.us/my/cschweik and by appointment 
Synchronous class Zoom meeting room (this will ALWAYS be the link to use):

https://umass-amherst.zoom.us/i/97113728521?pwd=M2tTZ2FqT1cxRjhHWlpBWkFBSzlkUT09

Passcode: 571378

Dial by your location

+16468769923 US (New York)

Meeting ID: 97113728521

Find your local number: https://umass-amherst.zoom.us/u/abYpx77hZX

$* * * * *$ ZOOM instructions $* * * * *$

Computer users:

- Scroll your mouse to the bottom of the zoom screen and you will see a black menu with a Participants option. If you click on that you will see the list of participants in a side window. Next to your name is a muted microphone and video icon.

- Please TURN OFF your video to keep our bandwidth use to a minimum.

- Please keep your microphone muted so background noise in your household doesn't interrupt us.

- If you want to say something either:

○ use the Chat function you can invoke from the black menu at the bottom and type in your question; or,

$\circ$ use the Raise Your Hand function at the bottom of the participants window.

○ I'll monitor both.

Phone users:

- If you want to say something, you can let me know if you have a question by dialing * $\mathbf{9}$ to raise your hand on my screen. I will see your hand raised and will unmute your phone so that you can ask your question.

\section{Course Description}

Over the last decade or more, there has been a detectable and growing dissatisfaction among students with the "status quo" in the way the society works. Students have witnessed terrorism, long-term war, a "great recession," the "Occupy" movement, effects of climate change and worse projections to come, and most recently, a global pandemic with a great impact on the economy. Many students are looking for models of hope and alternatives to the status quo on how society at local, regional and global levels might operate to collectively address problems.

In this course, we will review historical and contemporary commons cases. [Note: Some of you might ask: "What exactly are commons"? This will be a question we will examine throughout the course, but I include three different definitions or descriptions in the box on the next page.]

We will explore how these forms of social organization might be used to change the way we humans interact. Central to these discussions will be learning methods for studying commons governance, called "Institutional Analysis," and a focal activity in the course will be a project where we study the governance and management of one or more active commons cases. Our overall goal is to study and investigate both successful and unsuccessful cases, and get inspired. 
Topics we will cover:

- An overview of the commons and conceptualizing the commons - we will read two books by internationally known commons writer and activist, David Bollier (who will visit our class for at least one, possibly two sessions).

- The Institutional Analysis and Development (IAD) framework, a framework widely used by commons researchers to study aspects of the commons and commoning. It is also a more general tool for policy analysis.

- Historical commons.

- Commons case study in areas such as:

○ Traditional natural resource commons and current day innovations.

Urban commons

- Digital and Knowledge commons -- sometimes referred to as "new commons" as shown in the chart on the top of this syllabus. This will be a longer component of the class, for there is a significant activity in this area. Subtopics include: open access scholarly publishing; open science; data commons such as in the context of medicine; citizen science; open educational resources; open source hardware; Wifi-mesh networks; platform cooperatives; open design and manufacturing; makerspaces, fablabs and co-learning commons.

- Agriculture commons, such as community supported agriculture, slow food, agroecology, and permaculture.

- Important issues in commoning, such as

○ Financing

- A methods for assisting in governing a commons called "Sociocracy"

- Efforts to consider how we transition to a society with more focus on commons and commoning.

\begin{tabular}{l} 
Definitions of "commons" \\
From Anderies and Janssen, Sustaining the Commons (2013, p. 3) \\
The original meaning of the term "commons" comes from the way that communities managed shared \\
land in Medieval Europe. This shared land was not owned by any single individual but, rather, was \\
"held in common," thus the term "commons." Along with this shared land was a clear set of rules \\
developed by the community about how it was to be used. Technically, the term "commons" thus \\
refers to the land and the rules that go with it to govern its use. Over time, the term commons has \\
taken on several meanings. Most generally it can be used to refer to a broad set of resources, natural \\
and cultural, that are shared by many people. Examples of resources that are referred to as \\
"commons" include forests, fisheries, or groundwater resources that are accessible to members of the \\
community. The key term here is "shared." Forests, for example, need not be shared-there are many \\
examples of private forests. Thus, implicit in the term "commons" as it is frequently used today is that \\
there are no property rights established over the resource. That is, the resource is "open access." This \\
departs somewhat from the original meaning and has, unfortunately, caused some confusion as we \\
shall see later. Other examples of commons that the reader will encounter in everyday life include \\
open source software, Wikipedia, public roads, and public education. Throughout this book, we will \\
use the term "commons" to refer to a resource, or collection of resources over which private property \\
rights have not been established. \\
\hline From Bollier and Helfrich, Free, Fair and Alive: The Insurgent Power of the Commons (2019, 74) \\
Commons - Commoning - Commoner. A brief excursion into the etymology of these terms: each \\
\hline
\end{tabular}


word connects the Latin words cum and munus. Cum (English "with") denotes the joining of elements. Munus - which is also found in the word "municipality" - means service, duty, obligation, and sometimes gift. All terms that conjoin cum and munus, such as communion, community, communism, and, of course, communication, point to a co-obligation - a linkage between use rights, benefits, and duty. As Pierre Dardot and Christian Laval write, commons "not only designate what is pooled," but also the commoners themselves - "those who have 'duties in common."

Commons are a pervasive, generative, and neglected social lifeform. They are Complex, Adaptive, Living Processes that generate wealth (both tangible and intangible) through which people address their shared needs with minimal or no reliance on markets or states. A commons arises as people engage in the social practices of Commoning, participate in Peer Governance, and develop collaborative forms of Provisioning in the course of using a resource or care-wealth. While every commons is different, all ultimately depend on the physical gifts of nature, and on sharing, collaboration, mutual respect and Gentle Reciprocity. A commons is constantly becoming.

Every Commons arises through Commoning, which has three symbiotic aspects: Everyday Social Habits, Peer Governance, and Provisioning. This is the Triad of Commoning.

From Hess, Mapping the New Commons (2008: 37).

A commons is a resource shared by a group where the resource is vulnerable to enclosure, overuse and social dilemmas. Unlike a public good, it requires management and protection in order to sustain it.

\section{General Class Structure and Rules of the Game}

I understand fully that in this moment in the era of Covid-19 and all the fallout it is creating, flexibility and "radical compassion" is the way we should be operating and working with one another. Consequently, I've designed this seminar class to be as flexible to the student as possible, meaning that you can take this class:

1. synchronously (life, in person, over Zoom -- the preferred option);

2. asynchronously (completely offline on your own time), or,

3. as a "hybrid" (meaning you choose when you make the live sessions and when you will not).

You just need to communicate to me your preference, which I will solicit through a survey over email.

The synchronous class meets at Mondays and Wednesdays from 4:00-5:15 pm in the Zoom meeting room (See Box above on page 2 for Zoom information). For asynchronous or hybrid students, I will post the recorded class zoom meeting so you can watch it on your own time and hear what was discussed.

I will NOT be lecturing. This will be a seminar-type class. IMPORTANT: In order to have a successful class in this very strange environment we find ourselves in, this will be an exercise in co-production. We all want to make this class experience the BEST WE CAN MAKE IT from a standpoint of you LEARNING. This means, in this extraordinary time, this will be an exercise of CO-PRODUCTION in learning. I need your absolute commitment to do the best you can to prepare for class sessions and PARTICIPATE in our dialog in each and every class. This is especially important this semester, as I think I can safely say, we're all feeling isolated. My hope is that we will create a class culture of camaraderie, interesting discussion, co-learning, and as much as possible even fun and laughter. I truly hope that we can make a regular class session that you look forward to and it brings us joy to be together.

If you do the class asynchronously, I respectfully ask you to make every effort to provide commentary on class readings in Moodle forums a day before the synchronous class meets, so that we can review and potentially react to your points made in the synchronous meetings that will be recorded, for you to watch when time permits.

\section{Weekly expectations of Synchronous students:}

- Read assigned readings prior to class and really think about them; 
- Post reactions, thoughts, discussion questions or puzzles to Moodle forums a day before our class meets so Charlie can read/analyze them in preparation for our discussion.

- Attend the live bi-weekly zoom class sessions.

- Participate in the discussions. In many instances, the class will be discussion based on postings of moodle forum topics or in some cases driven by prompts by Charlie.

- Do all assignments described below.

- Communicate to Charlie anytime, when things don't feel like they are operating OK from your perspective, so he can help you and make any needed adjustments.

Weekly expectations of Asynchronous students:

- Read assigned readings prior to class and really think about them;

- Post reactions, thoughts, discussion questions or puzzles to Moodle forums a day before our class meets so Charlie can $\mathrm{read} /$ analyze them in preparation for the class live discussion (which you won't be expected to attend).

- Watch the post class recordings of our class meetings and email Charlie if you have follow-up puzzles or questions or clarifications to topics discussed.

- Do all assignments described below.

- Communicate to Charlie anytime, when things don't feel like they are operating OK from your perspective, so he can help you and make any needed adjustments.

Weekly expectations of Hybrid students:

- Depending on the class follow one or the other of the above (synchronous or asynchronous).

- Communicate to Charlie anytime, when things don't feel like they are operating OK from your perspective, so he can help you and make any needed adjustments.

\section{Assignments and Assessment/Grading}

1. Depending on the week, either (1) short Moodle forum posts reacting to the week's assigned readings to help us prepare for discussion, or (2) short live summaries to the class on a case reading when we get into areas in late September and October (20\%).

On memo weeks, they will need to be uploaded to Moodle a day before we meet so that I can review them and can use them to help guide our in-class discussions. Students who take this class asynchronously should also meet this requirement and depending on the topics raised we may discuss it in the live class.

2. Two case studies ( $20 \%$ each, $40 \%$ total) for starting a first ever "Massachusetts Commons Catalog", or one student can act as the "production editor" of the volume. In addition to the actual written cases for the catalog, you will be asked to give brief presentations on your cases on the last two classes before Thanksgiving. If, for some reason you don't like the local case options, we can explore you writing cases on an interesting commons topic for somewhere else in the world. For example, l'd love for someone to study our learning management system Moodle as a commons.

3. One more scientific analysis of a co-housing case $(20 \%)$. In this project I hope we can study, in more detail and depth, the governance of co-housing in a comparative approach. We will develop this study collaboratively -- and I am hopeful this will be really cool and hopefully fun.

4. Class reflection paper or special topic paper (20\%). The reflection paper will be a 7-10 page double spaced paper allowing you to reflect on the content in this class as it relates to your own personal interest areas. It is an opportunity to reflect on the topics and content and write, in a way, an essay to yourself about ideas on how it might apply to your interests and future career, or you could take a skeptical stance and raise issues or problems you encountered with ideas presented in the class. The special topic paper option is included if there is a student who has some different idea that they want to pursue, to help them move forward in some way.

5. Class participation, meaning contributions of pre-class session reflections/discussions and either Moodle forum (asynchronous) or live interaction in synchronous classes (20\%). Co-production in learning requires that you commit yourself to participating in this class and this class will be about what we can learn together rather than passive learning through 
instructor lectures. (Extra credit participation -- watch one or more webinars in the World Commons Week event from Sept 30-October 9th).

\section{Grade Distribution}

$\begin{array}{ll}\text { A } & >94 \\ \text { A- } & 90.0-94 \\ \text { B+ } & 87.5-89.9 \\ \text { B } & 82.5-87.4 \\ \text { B- } & 80.0-82.4 \\ \text { C+ } & 77.5-79.9 \\ \text { C } & 72.5-77.4 \\ \text { C- } & 70.0-72.4 \\ \text { D } & 60.0-69.9 \\ \text { F } & <60\end{array}$

\section{Reading materials}

WARNING. BE PREPARED TO READ. If you aren't prepared for that, this is not the class for you. This is a joint graduate and upper-level undergraduate seminar and the model, for nearly each class, will be pre-class readings, very short reactions to these readings as pre-class memos that we will use to drive our weekly conversations in co-learning about the old and new commons. The first month we will read most if not all of three books:

- David Bollier, 2014. Think Like a Commoner. I will be making this available in pdf form on Moodle. If you want a hardcopy, order it at https://newsociety.com/books/t/think-like-a-commoner.

- Bollier, David and Helfrich, 2019. Free, Fair and Alive: The Insurgent Power of the Commons. Freely available online at https://www.freefairandalive.org/read-it/. If you would rather have a printed copy, David has offered to sell copies for $\$ 10$ to you (just not sure how we would manage that in an online situation), or see this page to order it from the publisher: https://www.freefairandalive.org/order/.

- Anderies and Janssen, 2013. Sustaining the Commons. Pdf and e-book available at https://sustainingthecommons.org/. Unfortunately it is only available digitally. You can't order a print copy that I know of. If anyone absolutely needs print -- let me (Charlie) know.

- Baumans, Kostakis and Pazaitis, 2019. Peer to Peer - A Commons Manifesto. Pdf available at https://www.researchgate.net/publication/331910371 Peer to Peer The Commons Manifesto

- These and other individual papers will be linked on Moodle under their appropriate date.

\section{Course Schedule}

This schedule is tentative and subject to change, especially if I overestimated what we'd be able to cover in a given week. For an up-to-date schedule, ALWAYS use the Moodle calendar.

\begin{tabular}{|c|c|c|}
\hline Week & Unit & Date \\
\hline \multicolumn{3}{|c|}{ Part I: Understanding and Conceptualizing the Commons } \\
\hline 1 & Class introduction & 24 August \\
\hline 1 & Commons overview & 31 August \\
\hline 2 & Commons overview & 2 Sept \\
\hline 2 & Conceptualizing the commons: Bollier and Helfich's The Triad \\
\hline
\end{tabular}




\begin{tabular}{|c|c|c|}
\hline 3 & " " & 7 Sept \\
\hline 3 & " " & 9 Sept \\
\hline \multicolumn{3}{|c|}{ Part II. Studying the Commons } \\
\hline 4 & Governing the Commons Catalog project day & 14 Sept \\
\hline 4 & $\begin{array}{c}\text { Scientific study of the commons: The Institutional Analysis and } \\
\text { Development Framework }\end{array}$ & 16 Sept \\
\hline 5 & $\begin{array}{c}\text { Scientific study of the commons: The Institutional Analysis and } \\
\text { Development Framework }\end{array}$ & 21 Sept \\
\hline 5 & Co-housing project discussion and launch & 23 Sept \\
\hline \multicolumn{3}{|c|}{ Part III: Commons Cases } \\
\hline 6 & Historical Commons & 28 Sept \\
\hline 6 & Traditional Natural Resource Commons & 30 Sept \\
\hline 7 & Urban Commons (World Commons Week begins) & 5 October \\
\hline 7 & $\begin{array}{l}\text { Case lightning presentations (and World Commons Week } \\
\text { continues) }\end{array}$ & 7 October \\
\hline 8 & $\begin{array}{c}\text { Digital and Knowledge Commons (World Commons Week } \\
\text { ends) }\end{array}$ & 12 October \\
\hline 8 & " " & 14 October \\
\hline 9 & " " & 19 October \\
\hline 9 & " " & 21 October \\
\hline 10 & $\begin{array}{l}\text { Natural Resources - Current day innovations; Agriculture } \\
\text { commons }\end{array}$ & 26 October \\
\hline 10 & Financing the commons & 26 October \\
\hline 11 & Practical, real life governing the commons: Sociocracy & 02 November \\
\hline 11 & $\begin{array}{l}\text { Transitioning toward commoning; public policy and the } \\
\text { commons }\end{array}$ & 04 November \\
\hline 12 & Cohousing study comparison and discussion & 09 November \\
\hline 12 & Cohousing study comparison and discussion & 11 November \\
\hline 13 & Open class for discussion or commons catalog work & 16 November \\
\hline 13 & Last class. Final discussions, class evaluation & 18 November \\
\hline 14 & Thanksgiving break & 23 November \\
\hline 14 & Thanksgiving break & 25 November \\
\hline 15 & Finals week - Reflection paper due & 30 November \\
\hline 15 & & 4 December \\
\hline
\end{tabular}

A final note. The course is designed to meet the University Quality Standards for a "fully online course." Practically, this means:

The course is accessible through Moodle. 
Content delivery:

- The course is organized in Moodle chronologically by weeks and class sessions;

- Critical course content -- in this case ALL course content -- is provided asynchronously for students who cannot make the synchronous course times;

- All online class meetings will be recorded and made available for students to watch later if they cannot make the class time;

- Students will be provided with transcripts of each session that will be generated by Zoom; and,

- To the best of my ability, I will provide documents that adhere to accessibility standards. On this last point, if any student in the class finds any difficulty in accessing class material, please contact me so I can take measures to address whatever difficulty you may be having.

Engagement:

- Students will be provided opportunities to interact with me, the seminar facilitator and peers, during synchronous sessions and/or asynchronously through discussion forums or chats;

- Synchronous office hours are scheduled weekly (see office hours, above) and I am always available for individual meetings with students if they need/request it.

Faculty Student Communication

- A printable version of the syllabus is provided, here!

- The syllabus (this document) meets Faculty Senate guidelines;

- Synchronous class sessions are scheduled according to the times for the class in SPIRE;

- Clear expectations and norms for communication are provided in this document and will be repeated in our first class session.

Assessment

- I've worked to provide clear guidance for academic integrity expectations for the course assignments both in this document and on individual assignments;

- I will always support students who need flexibility because of Covid-19 related issues and for those with documented disabilities. At any time during the semester, please contact me if you need additional help in any way. I'm rooting for you and want this to be a really positive experience in spite of what is happening in the world around us right now. 